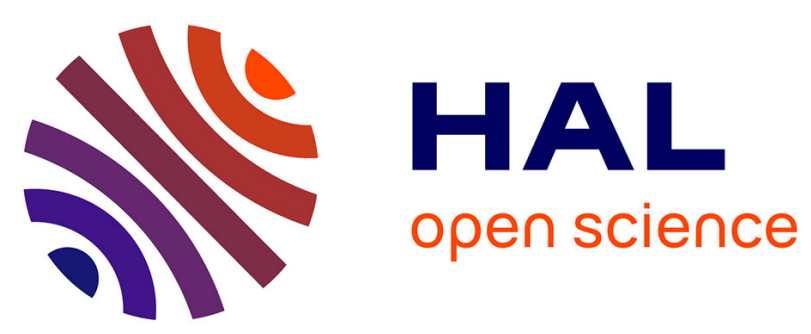

\title{
Preparation of CeSiO 4 from aqueous precursors under soft hydrothermal conditions
}

Paul Estevenon, Éléonore Welcomme, Stephanie Szenknect, Adel Mesbah, Philippe Moisy, Christophe Poinssot, Nicolas Dacheux

\section{To cite this version:}

Paul Estevenon, Éléonore Welcomme, Stephanie Szenknect, Adel Mesbah, Philippe Moisy, et al.. Preparation of $\mathrm{CeSiO} 4$ from aqueous precursors under soft hydrothermal conditions. Dalton Transactions, 2019, 48 (22), pp.7551-7559. 10.1039/C9DT01258C . hal-02360069

\section{HAL Id: hal-02360069 \\ https://hal.umontpellier.fr/hal-02360069}

Submitted on 18 Nov 2020

HAL is a multi-disciplinary open access archive for the deposit and dissemination of scientific research documents, whether they are published or not. The documents may come from teaching and research institutions in France or abroad, or from public or private research centers.
L'archive ouverte pluridisciplinaire HAL, est destinée au dépôt et à la diffusion de documents scientifiques de niveau recherche, publiés ou non, émanant des établissements d'enseignement et de recherche français ou étrangers, des laboratoires publics ou privés. 


\title{
Preparation of $\mathrm{CeSiO}_{4}$ from aqueous precursors under soft hydrothermal conditions
}

\author{
Paul Estevenon ${ }^{\mathrm{a}, \mathrm{b}}$, Eleonore Welcomme ${ }^{\mathrm{a}}$, Stephanie Szenknect ${ }^{\mathrm{b}}$, Adel Mesbah ${ }^{*}{ }^{\mathrm{b}}$, Philippe Moisy ${ }^{\mathrm{a}}$, \\ Christophe Poinssot ${ }^{\mathrm{a}}$, Nicolas Dacheux ${ }^{*}$

\begin{abstract}
Even though $\mathrm{CeSiO}_{4}$ was synthesized one time through a hydrothermal treatment, the conditions leading to its formation remain largely unknown. In order to define the optimized conditions of synthesis, a multiparametric study was developed by varying the $\mathrm{pH}$ of the solution, the temperature, the nature of the reactants and of the complexing ions in solution. This study highlighted that $\mathrm{CeSiO}_{4}$ could not be obtained starting from $\mathrm{Ce}(\mathrm{IV})$ reactants. An optimal set of conditions was defined to prepare single phase samples. Pure $\mathrm{CeSiO}_{4}$ was obtained through a hydrothermal treatment at $150^{\circ} \mathrm{C}$ using a starting mixture of $1 \mathrm{~mol} \cdot \mathrm{L}^{-1} \mathrm{Ce}(\mathrm{III})$ nitrate and $\mathrm{Na}_{2} \mathrm{SiO}_{3}$ solutions and by adjusting the initial $\mathrm{pH}$ to 8 . The chemical limitations observed during the synthesis of $\mathrm{CeSiO}_{4}$ suggested that the formation of this phase may result from the slow insitu oxidation of a $\mathrm{Ce}$ (III) silicate complex during the hydrothermal treatment.
\end{abstract}

\section{Introduction}

The synthesis of $\mathrm{Ce}(\mathrm{III})$ silicates has been extensively studied mainly because of their optoelectronic, catalytic and ion exchanger properties. ${ }^{1-11}$ The formation of cerium(III) silicates was also reported as secondary phases for cerium doped silicon nitride ceramics and cerium doped nuclear waste glasses. ${ }^{12}$ However, even if the formation of cerium(III) silicates is ubiquitous, only few information are available concerning the properties of the cerium(IV) silicate, because high temperature methods commonly used to prepare silicate based phases did not allow to form $\mathrm{CeSiO}_{4} \cdot{ }^{3}$ Indeed, thermodynamic calculations predicted that this phase was unstable compared to the mixture of corresponding oxides, $\mathrm{CeO}_{2}$ and $\mathrm{SiO}_{2}{ }^{13}$

Silicate species are abundant in environmental conditions, ${ }^{14}$ especially in potential geological sites dedicated to underground repository of radioactive waste. In such conditions, actinide elements could be in contact with silicate species coming from cement, glass waste form, granite or clay. This raises important questions regarding the interaction of silicate species and actinides and associated potential impact on actinide mobility in environmental conditions. Tetravalent actinide elements are often associated to very low mobility in environmental conditions due to the low solubility of actinide bearing hydroxides, i.e. $\mathrm{An}(\mathrm{OH})_{4}$, in neutral and alkaline media. ${ }^{15}$ Such a solubility could be significantly modified in the presence of silicate species in solution. Indeed, uranium(IV) and thorium(IV) are well known to form natural thorite ( $\left.\mathrm{ThSiO}_{4}\right)$, coffinite $\left(\mathrm{USiO}_{4}\right.$, second more abundant U(IV) bearing phase) and uranothorite solid solutions by alteration of the respective oxides. ${ }^{16-20}$ Moreover, actinide silicate colloids have been observed at room temperature for actinide(IV): Th(IV), $U(I V)$ and $N p(I V)$. Several authors showed that colloidal transport influenced significantly the mobility of actinides in environmental conditions. ${ }^{21-25}$ In the case of plutonium(IV), the formation of $\mathrm{PuSiO}_{4}$ and of plutonium silicate colloids was also suggested. ${ }^{26}$ The mechanism associated to their formation remained, however, largely unknown.
Cerium is commonly used as a surrogate for actinides, especially for plutonium due to some similarities in terms of ionic radius and chemical properties. First, $\mathrm{CeSiO}_{4}$ was reported to be isostructural with $\mathrm{ZrSiO}_{4}$ (space group 14 1 /amd), $\mathrm{HfSiO}_{4}$ and $\mathrm{AnSiO}_{4}$ (with $\mathrm{An}=\mathrm{Th}, \mathrm{Pa}, \mathrm{U}, \mathrm{Np}, \mathrm{Pu}$ and $\mathrm{Am}$ ). ${ }^{27-30}$ It has been reported as a natural occurring mineral phase of the zircon group by Schlüter et al. in $2009^{31}$ and named stetindite. The formation of synthetic $\mathrm{CeSiO}_{4}$ was formerly reported by Dickson and Glasser in 2000 during the study of cement alteration. $^{30,32}$ To the best of our knowledge, this protocol was the only reported in literature to prepare this phase. It consisted in the hydrothermal treatment $\left(55 \leq \mathrm{T} \leq 180^{\circ} \mathrm{C}\right.$ for 14 to 700 days) of a mixture containing cerium(III) nitrate solution, $\mathrm{SiO}_{2}$ and $\mathrm{CaO}$ dissolved in aqueous solution under inert atmosphere. From PXRD analyses, these authors reported the formation of a mixture of $\mathrm{CeSiO}_{4}$ and $\mathrm{CeO}_{2}$ for $\mathrm{T} \geq 130^{\circ} \mathrm{C}$ and of $\mathrm{CeSiO}_{4}$ as the only crystallized phase for $\mathrm{T} \leq 85^{\circ} \mathrm{C}$. However, due to the poor crystallinity of $\mathrm{CeO}_{2}$ precipitated at low temperatures, its presence in the final mixtures was not definitively discarded. Moreover, the role of $\mathrm{CaO}$ in these media remained largely unclear.

This work was thus dedicated to the preparation of oxide free $\mathrm{CeSiO}_{4}$ samples in order to get a set of thermodynamic experimental data associated to this phase. In this field, the comprehensive study of the formation of pure $\mathrm{CeSiO}_{4}$ samples with different aqueous precursors is reported here.

\section{Materials and methods}

\section{Preparation of $\mathrm{CeSiO}_{4}$}

All of the reagents used were of analytical grade and supplied by Sigma-Aldrich. $\mathrm{Na}_{2} \mathrm{SiO}_{3}$ was used as silicate precursor. $\mathrm{Ce}\left(\mathrm{NO}_{3}\right)_{3} \cdot 6 \mathrm{H}_{2} \mathrm{O}(99.9 \%)$ and $\mathrm{CeCl}_{3} \cdot 7 \mathrm{H}_{2} \mathrm{O}(99.9 \%)$ were used as $\mathrm{Ce}(\mathrm{III})$ precursors, whereas $\left(\mathrm{NH}_{4}\right)_{2} \mathrm{Ce}\left(\mathrm{NO}_{3}\right)_{6} \quad$ (99.99\%) and $\mathrm{Ce}\left(\mathrm{SO}_{4}\right)_{2}(99.9 \%)$ were considered for $\mathrm{Ce}(\mathrm{IV}) . \mathrm{NaHCO}_{3}$ was used as the carbonate source. $1.5 \mathrm{~mol} \cdot \mathrm{L}^{-1} \mathrm{HNO}_{3}, 1.5 \mathrm{~mol} \cdot \mathrm{L}^{-1} \mathrm{HCl}$ and $0.75 \mathrm{~mol} \cdot \mathrm{L}^{-1} \mathrm{H}_{2} \mathrm{SO}_{4}$ solutions were prepared by dilution of Sigma Aldrich ACS grade solutions: $\mathrm{HNO}_{3}(70 \%), \mathrm{HCl}(37 \%)$ and $\mathrm{H}_{2} \mathrm{SO}_{4}(95-98 \%) .8 \mathrm{~mol} \cdot \mathrm{L}^{-1} \mathrm{NaOH}$ solution was freshly 
prepared from Sigma Aldrich ACS grade $\mathrm{NaOH}$ (98\%) before the experiments. Aqueous silicate solutions were prepared by dissolving $\mathrm{Na}_{2} \mathrm{SiO}_{3}$ and the cerium precursor in acidic solutions (which nature depended on the cerium precursor used). The $\mathrm{pH}$ was then adjusted to the final expected value with $8 \mathrm{~mol} \cdot \mathrm{L}^{-1}$ $\mathrm{NaOH}$. The experiments were performed either in air or under inert conditions (Ar-atmosphere glove box).

All the mixtures were put in Teflon lined reactors in Parr autoclaves and then treated under hydrothermal conditions during 1 to 20 days with a temperature ranging from $40^{\circ} \mathrm{C}$ to $250^{\circ} \mathrm{C}$ and under autogenous pressure (Table S1). Reference conditions were fixed to 10 days of hydrothermal treatment at $150^{\circ} \mathrm{C}$. Thus, the final precipitates were separated from the supernatant by centrifugation for $12 \mathrm{~min}$ at $14000 \mathrm{rpm}$, washed twice with deionized water and once with ethanol, and then finally dried overnight at $60^{\circ} \mathrm{C}$ in an oven.

\section{Characterizations}

PXRD data were collected on the resulting powders using the Bruker D8 advance diffractometer equipped with a lynxeye detector and using $\mathrm{Cu} K \alpha$ radiation $(\lambda=1.54184 \AA$ ) in a reflection geometry (parallel beam). PXRD patterns were recorded between $5^{\circ}$ and $100^{\circ}(2 \theta)$ with steps of $0.019^{\circ}$ and a total counting time of 2.5 to 3 hours per sample. Pure silicon was used as a standard material to extract the instrumental function. Therefore, all the collected data were refined by the Rietveld method using the Fullprof suite package. ${ }^{33}$ During the refinements, different profile and structural parameters were allowed to vary, such as the zero shift, unit-cell parameters, scale factor, and overall displacement factor. However, the occupancy of each site was fixed to the calculated values.

Raman spectra were recorded with a Horiba-Jobin Yvon Aramis device equipped with an edge filter and a Nd:YAG laser (532 $\mathrm{nm}$ ) that delivers $60 \mathrm{~mW}$ at the sample surface. In order to avoid any laser-induced degradation of the compound, the power was turned down by the means of optical filters. The laser beam was then focused on the sample using an Olympus BX 41 microscope with an X50LMP objective, resulting in a spot area of $\sim 1 \mu^{2}$ and a power of $475 \mu \mathrm{W}$. For each spectrum, a dwell time ranging from 30 to $600 \mathrm{~s}$ was used. Four scans were performed to average the measurement error. For each sample, the data were collected on different areas.

FTIR spectra were recorded in the $300-4000 \mathrm{~cm}^{-1}$ range thanks to a Perkin-Elmer FTIR Spectrum 100 device. Powdered samples were deposited on the surface of an ATR crystal without any prior preparation. The spectra collected in such operating conditions exhibited a resolution lower than $4 \mathrm{~cm}^{-1}$. Four scans were performed to average the measurement error.

SEM observations were directly conducted on small aliquots of samples without prior preparation such as metallization, using a FEI Quanta 200 electronic microscope, equipped either with an Everhart-Thornley Detector (ETD) or a Back-Scattered
Electron Detector (BSED), under high vacuum conditions with a very low accelerating voltage $(2-3.1 \mathrm{kV})$. These conditions were chosen in order to create a beam deceleration effect that led to high resolution images.

Speciation calculations were performed using the PHREEQC 2 software ${ }^{34}$ and the thermochimie_PHREEQC_SIT_v9 database, ${ }^{35}$ combined with the thermodynamic constants available in Table $\mathbf{S 2}$ in order to determine the speciation of cerium in the reactive media.

\section{Results and discussion}

As already mentioned, the only protocol reported for the preparation of $\mathrm{CeSiO}_{4}$ was developed by Dickson and Glasser. ${ }^{30,} 32$ It consisted in preparing an equimolar mixture of lime, silica and cerium(III) nitrate in aqueous solution under inert atmosphere. This mixture was submitted to hydrothermal treatment between 55 and $180^{\circ} \mathrm{C}$ for 14 to 700 days. The precise role of $\mathrm{CaO}$ and redox reactions involving cerium were not clearly understood. The syntheses of the tetravalent actinide silicates, which are analogs of $\mathrm{CeSiO}_{4}$, are usually performed in the presence of carbonate ions. ${ }^{27,} 36,37$ However, it was recently reported that pure $\mathrm{ThSiO}_{4}$ can be prepared without adding carbonate ions. ${ }^{38}$ All these chemical routes have been explored with the aim to prepare pure $\mathrm{CeSiO}_{4}$. Especially, the protocols described by Costin et al. for uranothorite solid solutions $\mathrm{Th}_{x} \mathrm{U}_{1-\mathrm{x}} \mathrm{SiO}_{4}{ }^{39-44}$, or other recently developed for $\mathrm{ThSiO}_{4}{ }^{37,38}$, and described by Dickson et al. for $\mathrm{CeSiO}_{4}{ }^{30,32}$ were adapted.

\section{Preparation of $\mathrm{CeSiO}_{4}$ from $\mathrm{Ce}$ (IV) precursors}

Experiments developed in the absence of carbonate species in the reactive media. Attempts to prepare $\mathrm{CeSiO}_{4}$ from $\mathrm{Ce}(\mathrm{IV})$ precursors were performed with starting cerium and silicon concentrations ranging from $4.2 \times 10^{-2} \mathrm{~mol} \cdot \mathrm{L}^{-1}$ and $0.21 \mathrm{~mol} \cdot \mathrm{L}^{-1}$ whereas the initial $\mathrm{pH}$ of the reactive media was varying from $\mathrm{pH}=1$ to $\mathrm{pH}=12$. Hydrothermal treatment were performed

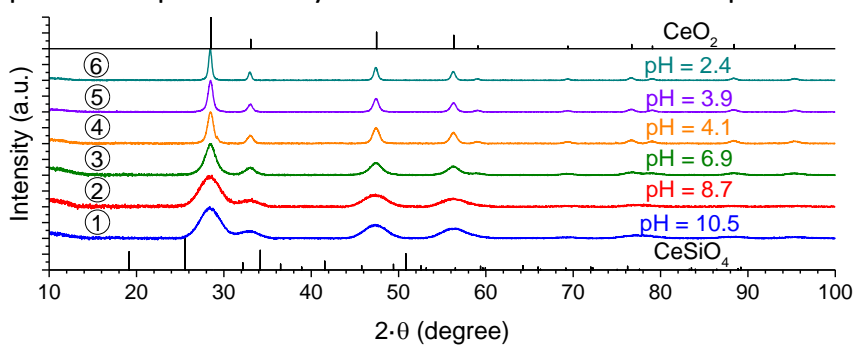

Figure 1. PXRD patterns obtained for samples prepared under hydrothermal conditions $\left(7\right.$ days, $\mathrm{T}=250^{\circ} \mathrm{C}$ ) with starting silicate and cerium(IV) concentrations of $4.2 \times 10^{-2} \mathrm{~mol} \cdot \mathrm{L}^{-1}$ and initial $\mathrm{pH}$ value equal to 10.5 (1), 8.7 (2), 6.9 (3), 4.1 (4), 3.9 (5) and 2.4 (6). Characteristic XRD lines of $\mathrm{CeO}_{2}$ and $\mathrm{CeSiO}_{4}$ were extracted from ref 30 and 45 , respectively.

with temperatures and holding times ranging from $90^{\circ} \mathrm{C}$ to $250^{\circ} \mathrm{C}$ and from 7 to 10 days, respectively. 
All the attempts to prepare $\mathrm{CeSiO}_{4}$ were unsuccessful. From PXRD characterization, only mixtures of $\mathrm{CeO}_{2}$ and amorphous $\mathrm{SiO}_{2}$ were observed (Figure 1). Moreover, the increase of the FWHM of the XRD lines associated to $\mathrm{CeO}_{2}$ was noted when increasing the $\mathrm{pH}$ of the starting mixture, as the consequence of the decrease of the crystallite size. These results were explained by the rapid hydrolysis of $\mathrm{Ce}$ (IV) which happened even at low $\mathrm{pH}$ values and prevented any complexation of cerium by silicate species. ${ }^{46}$ This explanation may be also supported by thermodynamic considerations. Indeed, the formation of $\mathrm{CeSiO}_{4}$ is expected to be strongly disfavored compared to the mixture of $\mathrm{CeO}_{2}$ and $\mathrm{SiO}_{2}$. ${ }^{13}$

The IR spectra recorded for $\mathrm{pH}<8$ were characteristic of amorphous $\mathrm{SiO}_{2}$ (Figure S1). On the contrary, they did not indicate the presence of $\mathrm{SiO}_{2}$ or $\mathrm{CeO}_{2}$ for $\mathrm{pH}>8$ but may correspond to the sorption or integration of silicate species in the structure of $\mathrm{CeO}_{2}$ similar to those observed for the sorption of silicate species on the surface of actinides oxides. ${ }^{47}$ 48

Experiments developed in the presence of carbonate species in the reactive media. For several actinides, the synthesis performed in the presence of carbonate species led to the formation of $\mathrm{AnSiO}_{4}$ even if they are unstable compared to a mixture of $\mathrm{SiO}_{2}$ and $\mathrm{AnO}_{2}$, as it was observed for metastable coffinite $\mathrm{USiO}_{4}{ }^{36,49}$ or predicted for $\mathrm{PuSiO}_{4}{ }^{27}$ according to ab initio calculations. ${ }^{13,27}$

Several attempts to prepare $\mathrm{CeSiO}_{4}$ in carbonate ions rich reactive media have been performed with starting cerium and silicate concentrations ranging from $4.2 \times 10^{-2} \mathrm{~mol} \cdot \mathrm{L}^{-1}$ and $0.21 \mathrm{~mol} \cdot \mathrm{L}^{-1}$, initial $\mathrm{pH}$ of the reactive media varying from $\mathrm{pH}=$ 8.7 to 12 and for hydrothermal treatment performed during 7 to 10 days with temperatures between $150^{\circ} \mathrm{C}$ and $250^{\circ} \mathrm{C}$. PXRD diagrams of the samples prepared are reported in Figure $\mathbf{2}$ for the various initial conditions examined. Unlike other tetravalent actinide silicates, $\mathrm{CeSiO}_{4}$ was never formed using these conditions (Figure 2). This specific behavior of cerium(IV) could result from the stronger complexation constants of carbonate species with cerium and from the different stoichiometry of the limiting complexes obtained for cerium,

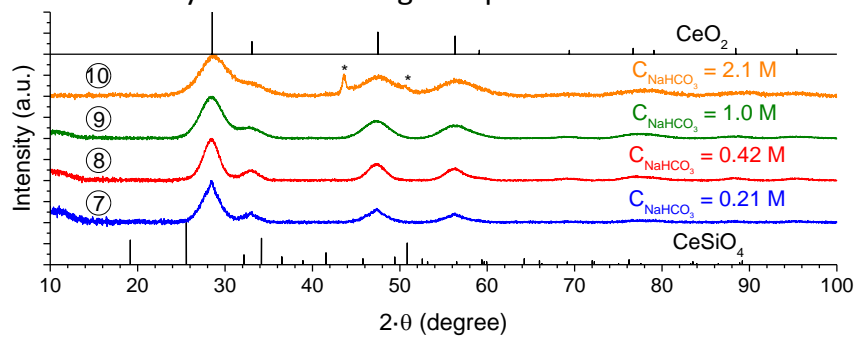

Figure 2. PXRD patterns obtained for samples prepared under hydrotherma conditions ( 10 days, $T=150^{\circ} \mathrm{C}$ ) with starting silicate and cerium(IV) concentrations of $0.21 \mathrm{~mol} \cdot \mathrm{L}^{-1}$ and initial $\mathrm{pH}$ value equal to 8.7 and with $\mathrm{NaHCO}_{3}$ concentration equal to $0.21 \mathrm{~mol} \mathrm{~L}^{-1}(7), 0.42 \mathrm{~mol} \mathrm{~L}^{-1}(8), 1.0 \mathrm{~mol} \mathrm{~L}^{-1}$ (9) and $2.1 \mathrm{~mol} \mathrm{~L}^{-1}(10)$. XRD lines of the sample holder are pointed out by an asterisk Characteristic XRD lines of $\mathrm{CeO}_{2}$ and $\mathrm{CeSiO}_{4}$ were extracted from ref $\mathbf{3 0}$ and $\mathbf{4 5}$ respectively.
$\mathrm{Ce}\left(\mathrm{CO}_{3}\right)_{6}^{8-50}$ and actinides, $\mathrm{An}\left(\mathrm{CO}_{3}\right)_{5}^{6-51}$ in carbonate media. Both aspects would induce the decrease of the cerium availability as the consequence of the strong interactions with carbonate species (Table 1 ) leading to the formation of the cerium hexacarbonate complex and preventing other ligands to interact with the metal due to steric constraints.

Table 1. Constants of complexation of $\mathrm{Ce}$ (IV) and An(IV) with carbonate associated to the limit complexes at $\mathrm{I}=0\left(25^{\circ} \mathrm{C}\right)$

\begin{tabular}{cccc}
\hline $\operatorname{Ln} / \mathrm{An}$ & $\log \left(\boldsymbol{\beta}_{5}^{\circ}\right)^{*}$ & $\log \left(\boldsymbol{\beta}_{6}^{\circ}\right)^{*}$ & Reference \\
\hline $\mathrm{Th}$ & $31.0 \pm 0.7$ & --- & 52 \\
$\mathrm{U}$ & $34.0 \pm 0.9$ & --- & $\mathbf{5 3}$ \\
$\mathrm{Np}$ & $35.6 \pm 1.1$ & --- & 53 \\
$\mathrm{Pu}$ & $35.7 \pm 1.1$ & --- & $\mathbf{5 3}$ \\
$\mathrm{Ce}$ & $\leq 41.8 \pm 0.5$ & $42.2 \pm 0.5$ & $\mathbf{5 0}$ \\
\hline
\end{tabular}

$* \beta_{n}^{\circ}$ is associated to the reaction $\mathrm{An}^{4+}+\mathrm{n} \mathrm{CO}_{3}{ }^{2-}=\mathrm{An}\left(\mathrm{CO}_{3}\right)_{\mathrm{n}}{ }^{(2 \mathrm{n}-4)-}$.

\section{Preparation of $\mathrm{CeSiO}_{4}$ from $\mathrm{Ce}$ (III) precursors in solution.}

Impact of the initial $\mathrm{pH}$ and concentrations of reactants on the formation of $\mathrm{CeSiO}_{4}$ in nitric acid media. Since hydrolysis and complexation by carbonate ions are strongly unfavorable to the formation of pure $\mathrm{CeSiO}_{4}$, complementary experiments have been performed starting from Ce(III) precursors. With this aim, the syntheses were developed from mixtures of $\mathrm{Ce}$ (III) and silicate ions with starting concentrations of $0.21 \mathrm{~mol} \cdot \mathrm{L}^{-1}$ and initial $\mathrm{pH}$ values ranging from $\mathrm{pH}=1.3$ to 12.3 . The hydrothermal treatments were performed during 10 days at $150^{\circ} \mathrm{C}$ under inert atmosphere (Ar). The PXRD of the samples obtained are reported in Figure 3. It is worth noting that the formation of $\mathrm{CeSiO}_{4}$ was observed in a small range of $\mathrm{pH}$, i.e. between 7 and 9 . Moreover, it was not obtained as a pure phase. Indeed, the formation of $\mathrm{CeSiO}_{4}$ was limited by that of $\mathrm{CeO}_{2}$ whether at higher and at lower $\mathrm{pH}$ values. Complementary characterization by IR spectroscopy (Figure S2) revealed the presence of $\mathrm{SiO}_{2}$ for $\mathrm{pH}<7$ whereas it suggested the integration of silica in the lattice of cerium

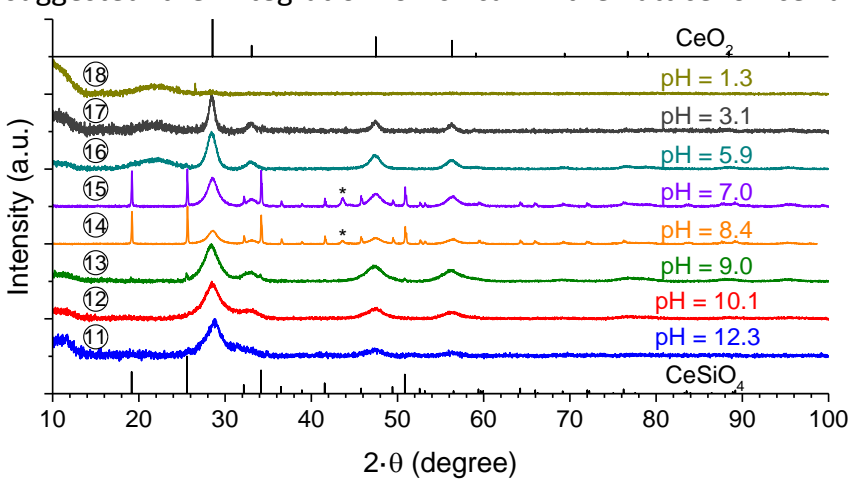

Figure 3. PXRD patterns obtained for samples prepared under hydrothermal conditions $\left(10\right.$ days, $\mathrm{T}=150^{\circ} \mathrm{C}$ ) with starting silicate and cerium(III) concentrations of $0.21 \mathrm{~mol} \cdot \mathrm{L}^{-1}$, in nitric acid media and with an initial pH equal to 12.3 (11), 10.1 (12), 9.0 (13), 8.4 (14), $7.0(15), 5.9(16), 3.1(17)$ and $1.3(18)$. XRD lines of the sample holder are pointed out 
by an asterisk. Characteristic XRD lines of $\mathrm{CeO}_{2}$ and $\mathrm{CeSiO}_{4}$ were extracted from ref $\mathbf{3 0}$ and 45 , respectively.

dioxide or the sorption of silicate ions on the surface of the samples for the $\mathrm{pH}>9$, as already described for thorium. ${ }^{47}$

Working with higher cerium and silicate concentrations (typically $\mathrm{C}_{\mathrm{Ce}} \approx \mathrm{C}_{\mathrm{Si}} \approx 1.0 \mathrm{~mol} \cdot \mathrm{L}^{-1}$ ) did not affect the $\mathrm{pH}$ range in which $\mathrm{CeSiO}_{4}$ was formed (Figure 4). However, the comparison of the data reported for both concentrations showed the significant increase of the relative content of $\mathrm{CeSiO}_{4}$ (compared to $\mathrm{CeO}_{2}$ ) in the mixture when increasing the initial cerium and silicate concentrations. This result was in good agreement with that obtained for $\mathrm{ThSiO}_{4}{ }^{37,}, 38$ for which high concentrations of reactants appeared to improve the yield of formation of the silicate phase. In order to fix the better conditions associated to the preparation of $\mathrm{CeSiO}_{4}$, Rietveld refinement of the PXRD data was performed (Figure 5). From the results reported in Figure 4 and in Figure 5, the maximum relative content of $\mathrm{CeSiO}_{4}$ in the prepared mixtures was obtained for concentrations of reactants of $1.0 \mathrm{~mol} \cdot \mathrm{L}^{-1}$ and for $\mathrm{pH}=8.2$.

Although the results confirmed the synthesis of $\mathrm{CeSiO}_{4}$ from $\mathrm{Ce}$ (III) precursor as described by Dickson et al. ${ }^{30,32}$, we can conclude from this study that $\mathrm{CaO}$ does not play any important role during the synthesis. In order to increase the recovery yield of $\mathrm{CeSiO}_{4}$, several experiments were unsuccessfully

年)

Figure 4. PXRD patterns obtained for samples prepared under hydrothermal conditions $\left(10\right.$ days, $\left.\mathrm{T}=150^{\circ} \mathrm{C}\right)$ with starting silicate and cerium(III) concentrations of $1.0 \mathrm{~mol} \cdot \mathrm{L}^{-1}$, in nitric acid media and with an initial pH equal to $8.7(19), 8.6(20)$, $8.2(21), 7.8$ (22), $7.4(23)$ and 7.0 (24). Characteristic XRD lines of $\mathrm{CeO}_{2}$ and $\mathrm{CeSiO}_{4}$ were extracted from ref $\mathbf{3 0}$ and $\mathbf{4 5}$, respectively.

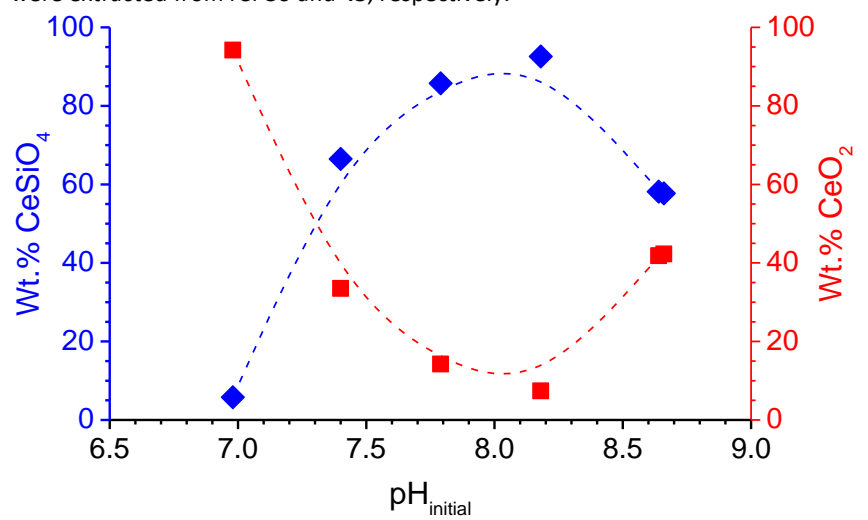

Figure 5. Relative contents of $\mathrm{CeSiO}_{4}$ and $\mathrm{CeO}_{2}$ (expressed in wt.\%) determined by Rietveld refinement of the PXRD patterns of samples prepared under hydrothermal conditions $\left(10\right.$ days, $\left.\mathrm{T}=150^{\circ} \mathrm{C}\right)$, with starting silicate and cerium(III) concentrations of $1.0 \mathrm{~mol} \cdot \mathrm{L}^{-1}$, in nitric acid media and for various initial $\mathrm{pH}$ values. performed by using over-stoichiometric amounts of silicate compared to cerium. Furthermore, additional syntheses performed in air led to lower reaction yields than those obtained under argon atmosphere. This difference was assigned to the rapid oxidation of $\mathrm{Ce}$ (III) into $\mathrm{Ce}$ (IV) under aerated conditions, ${ }^{54}$ which led to the rapid precipitation of cerium tetrahydroxide, then finally to $\mathrm{CeO}_{2}$ by ageing. ${ }^{46}$

Impact of the heating temperature on the formation of $\mathrm{CeSiO}_{4}$ in nitric acid media. In order to underline the impact of the temperature of the hydrothermal treatment on the yield of formation of $\mathrm{CeSiO}_{4}$, various experiments were performed between $90^{\circ} \mathrm{C}$ and $250^{\circ} \mathrm{C}$ during 10 days, with starting cerium and silicate concentrations of $0.21 \mathrm{~mol} \cdot \mathrm{L}^{-1}$ and initial $\mathrm{pH}$ values ranging from $\mathrm{pH}=7$ to $\mathrm{pH}=9$. The PXRD diagrams of the samples obtained are plotted in Figure $\mathbf{6}$ for several temperatures of hydrothermal treatment. It is worth noting that $\mathrm{CeSiO}_{4}$ was formed only between $90^{\circ} \mathrm{C}$ and $150^{\circ} \mathrm{C}$. At higher temperatures $\left(\mathrm{T} \geq 170^{\circ} \mathrm{C}\right)$, only crystallized $\mathrm{CeO}_{2}$ was formed whereas at lower temperatures, the amount of $\mathrm{CeO}_{2}$ formed as a by-product of the synthesis was difficult to quantify because of its poorly crystallinity for $\mathrm{T}<120^{\circ} \mathrm{C}$. However, even for the lower temperatures studied, the formation of $\mathrm{CeO}_{2}$ was evidenced by Raman spectroscopy, whereas that of amorphous $\mathrm{SiO}_{2}$ was confirmed by IR spectroscopy (Figure S3).

Figure 6. PXRD patterns obtained for samples prepared with starting silicate and cerium(III) concentrations of $0.21 \mathrm{~mol} \cdot \mathrm{L}^{-1}$, in nitric acid media and with an initial $\mathrm{pH}$ ranging from 7 to 8 , after hydrothermal treatment during 10 days at $90^{\circ} \mathrm{C}(25)$, $130^{\circ} \mathrm{C}(26), 150^{\circ} \mathrm{C}(27), 170^{\circ} \mathrm{C}(28)$ and $250^{\circ} \mathrm{C}$ (29). Characteristic XRD lines of $\mathrm{CeO}_{2}$ and $\mathrm{CeSiO}_{4}$ were extracted from ref 30 and $\mathbf{4 5}$, respectively.

Figure 7. PXRD patterns for samples prepared with starting silicate and cerium(III) concentrations of $1.0 \mathrm{~mol} \cdot \mathrm{L}^{-1}$, in nitric acid media with initial an $\mathrm{pH}$ equal to 7 at various temperature: $\mathrm{T}=40^{\circ} \mathrm{C}(30)$, and $\mathrm{T}=60^{\circ} \mathrm{C}(31)$. XRD lines of sample holder are pointed out by an asterisk. Characteristic XRD lines of $\mathrm{CeO}_{2}$ and $\mathrm{CeSiO}_{4}$ were extracted from ref $\mathbf{3 0}$ and $\mathbf{4 5}$, respectively.

Figure 8. Variation of the lattice parameters $a$ and $c$ of $\mathrm{CeSiO}_{4}$ versus the temperature of hydrothermal treatment. Dash lines correspond to the unit cell parameters obtained after heating the samples at $1000^{\circ} \mathrm{C}$ (considered as reference values).

The optimal conditions to prepare $\mathrm{CeSiO}_{4}$ were found to be $\mathrm{pH}=8.0$ and $\mathrm{T}=150^{\circ} \mathrm{C}$. Performing the syntheses at lower or
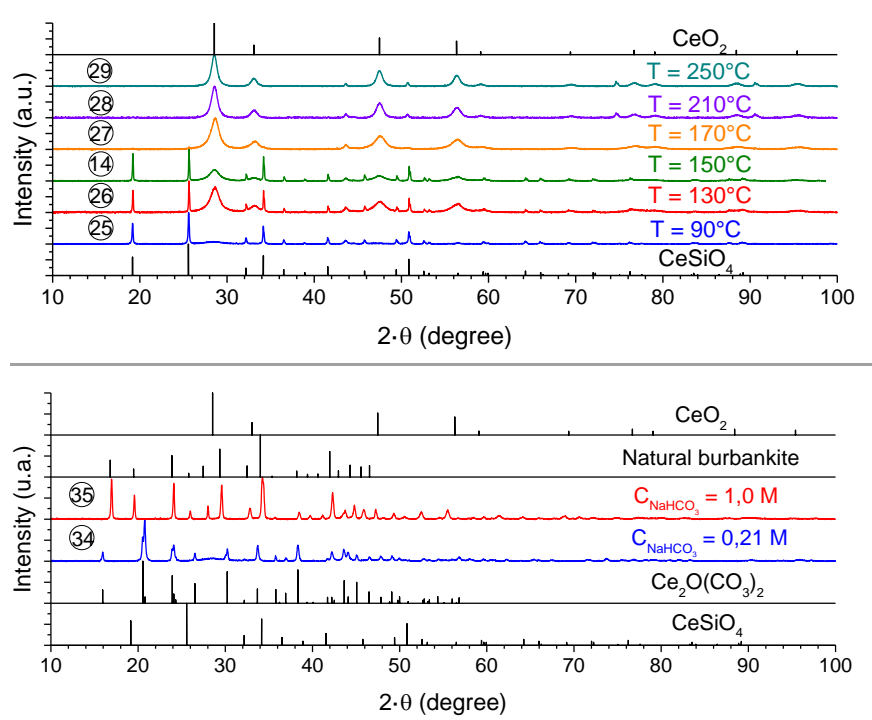


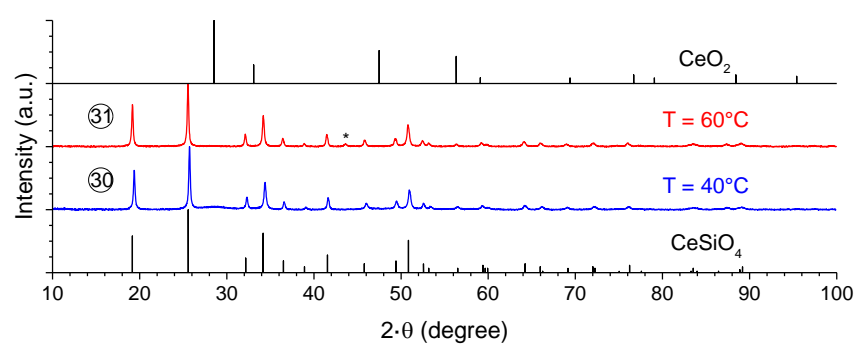

higher $\mathrm{pH}$ values led to the significant decrease of the yield of formation of $\mathrm{CeSiO}_{4}$ (and thus to the formation of higher amounts of $\mathrm{CeO}_{2}$ and $\mathrm{SiO}_{2}$ ). It has been observed that, at $90^{\circ} \mathrm{C}$,

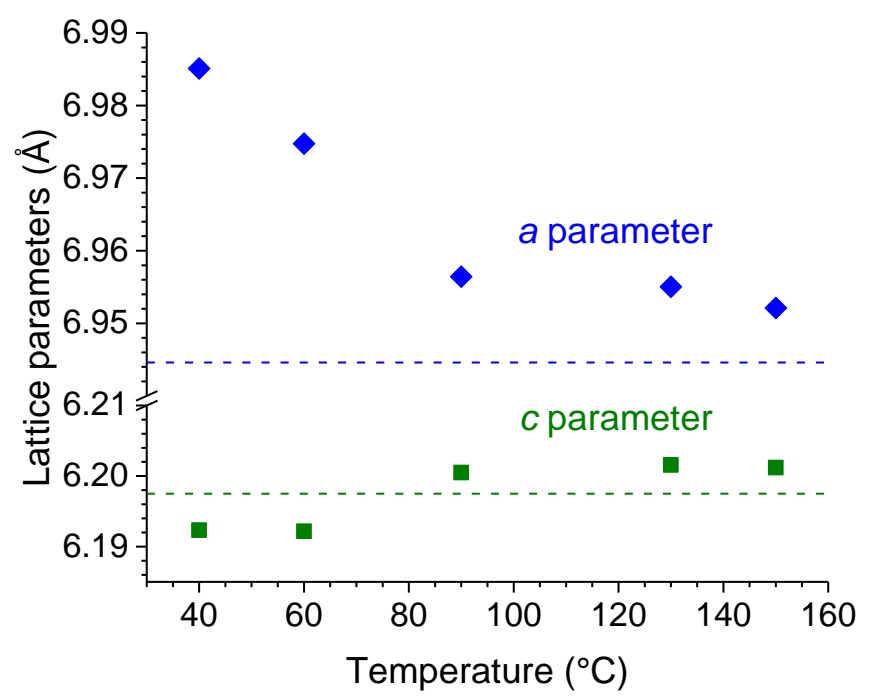

the optimum $\mathrm{pH}$ value was shifted to lower values (i.e. $\mathrm{pH}=7$ ), probably because of the dependence of the water selfionization constant with temperature. Moreover, it is worth noting that the extension of the holding time of the hydrothermal treatment up to 210 days at $40^{\circ} \mathrm{C}$ or up to 52 days at $60^{\circ} \mathrm{C}$ also led to the formation of $\mathrm{CeSiO}_{4}$ (cerium and silicate concentrations of $1.0 \mathrm{~mol} \cdot \mathrm{L}^{-1}$ and $\mathrm{pH}=7$ ) (Figure 7).

As it was reported for $\mathrm{ThSiO}_{4}{ }^{38,55}$ the synthesis temperature of $\mathrm{CeSiO}_{4}$ affected the lattice parameters of the crystallized phase. Indeed, the decrease of the $a$ lattice parameter and the increase of the $c$ lattice parameter were observed when the temperature increased (Figure 8). As inferred for $\mathrm{ThSiO}_{4}{ }^{38,55}$ this evolution could result from the elimination of hydroxide groups inserted in the silicate phase when increasing heating temperature.

Figure 9. PXRD patterns obtained for a sample prepared under hydrotherma conditions during 10 days at $\mathrm{T}=150^{\circ} \mathrm{C}$ with starting silicate and cerium(III) concentrations of $0.21 \mathrm{~mol} \cdot \mathrm{L}^{-1}$, in hydrochloric acid and with $\mathrm{pH}=8.5$. PXRD obtained before (32) and after washing step in $6 \mathrm{~mol} \cdot \mathrm{L}^{-1} \mathrm{HNO}_{3}$. Characteristic XRD lines of $\mathrm{CeO}_{2}, \mathrm{CeSiO}_{4}$ and $\mathrm{Sm}(\mathrm{OH})_{2} \mathrm{Cl}$ were extracted from ref 30, 45 and 56 respectively.

Finally, the stability of $\mathrm{CeSiO}_{4}$ under hydrothermal conditions was examined at $250^{\circ} \mathrm{C}$ by contacting $\mathrm{CeSiO}_{4}$ with solution for different $\mathrm{pH}$. No proof of the $\mathrm{CeSiO}_{4}$ degradation was obtained

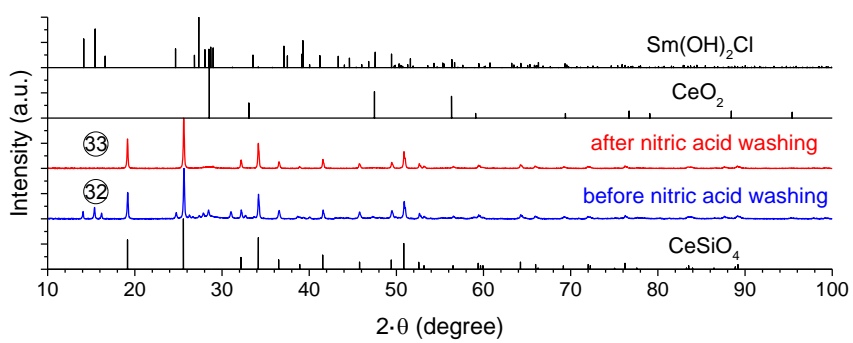

during these experiments. Therefore, it may inferred that the impact of temperature on the preparation of pure $\mathrm{CeSiO}_{4}$ did not result from the metastability of this phase. It is surely associated to the degradation of intermediate species required to form $\mathrm{CeSiO}_{4}$ instead of $\mathrm{CeO}_{2}$ in the final samples.

Preparation of $\mathrm{CeSiO}_{4}$ in hydrochloric acid medium. Several syntheses were performed in hydrochloric media using $\mathrm{CeCl}_{3}$ as starting precursor. The results followed roughly the same trend than in nitric acid solution. However, the formation of $\mathrm{CeSiO}_{4}$ in these conditions was limited by the formation of cerium hydroxyl-chloride, $\mathrm{Ce}(\mathrm{OH})_{2} \mathrm{Cl}$ which formed in the same $\mathrm{pH}$ range (Figure 9). $\mathrm{Ce}(\mathrm{OH})_{2} \mathrm{Cl}$ is isostructural to $\mathrm{Ln}(\mathrm{OH})_{2} \mathrm{Cl}$ phases which were formed under hydrothermal conditions in experimental conditions close to those developed in this study. ${ }^{57,58}$ Due to its high solubility in nitric acid, a washing step of 10 minutes with $1 \mathrm{M}$ nitric acid after the synthesis allowed to dissolve specifically the $\mathrm{Ce}(\mathrm{OH})_{2} \mathrm{Cl}$ phase leading to a $\mathrm{CeSiO}_{4}$ and $\mathrm{CeO}_{2}$ mixture (Figure 9).

The direct comparison of the results obtained in nitric and hydrochloric media showed that oxidation of cerium(III) to cerium(IV) necessary to form $\mathrm{CeSiO}_{4}$ was not only due to the presence of nitrate ions. Residual oxygen dissolved in water could contribute to this oxidation reaction.

Figure 10. PXRD patterns for the samples prepared under hydrothermal conditions during 10 days at $\mathrm{T}=150^{\circ} \mathrm{C}$ with starting silicate and cerium(III) concentrations of $0.21 \mathrm{~mol} \cdot \mathrm{L}^{-1}$, with $\mathrm{pH}_{\text {initial }}=8.7$ and carbonate concentration of $0.21 \mathrm{~mol} \cdot \mathrm{L}^{-1}(34)$ or $1.0 \mathrm{~mol} \cdot \mathrm{L}^{-1}(35)$. Characteristic XRD lines of $\mathrm{CeO}_{2}, \mathrm{CeSiO}_{4}, \mathrm{Ce}_{2} \mathrm{O}\left(\mathrm{CO}_{3}\right)_{2}$ and natural burbankite, $(\mathrm{Na}, \mathrm{Ca})_{3}(\mathrm{Ca}, \mathrm{Sr}, \mathrm{Ba}, \mathrm{Ln})_{3}\left(\mathrm{CO}_{3}\right)_{5}$, were extracted from references ref $\mathbf{3 0}, \mathbf{4 5}$ 61 and 60 , respectively.

Preparation of $\mathrm{CeSiO}_{4}$ in carbonate media. Several attempts to use carbonate ions as $\mathrm{pH}$ buffer in the reactive media and/or as complexing agent of cerium to increase its availability, thus its reactivity with silicate species did not lead to the formation of $\mathrm{CeSiO}_{4}$. The main limitation was the formation of cerium(III) carbonate based species, such as $\mathrm{Ce}(\mathrm{OH}) \mathrm{CO}_{3}$ under hydrothermal conditions at $150^{\circ} \mathrm{C}$ as observed by Guo et al. ${ }^{59}$, and burbankite type phases ${ }^{60} \mathrm{Na}_{4} \mathrm{Ce}_{2}\left(\mathrm{CO}_{3}\right)_{5}$, for higher carbonate concentrations (Figure 10). Moreover, increasing the temperature of the hydrothermal treatment led to the decomposition of such cerium carbonate species to form cerium oxide (mixed with amorphous silica) without any trace of $\mathrm{CeSiO}_{4}$. These results indicated that the complexation of $\mathrm{Ce}$ (III) with carbonate ions was more favorable than with silicate species (see Figure $\mathbf{1 3}$ and Figure $\mathbf{5 9}$ thereafter). 


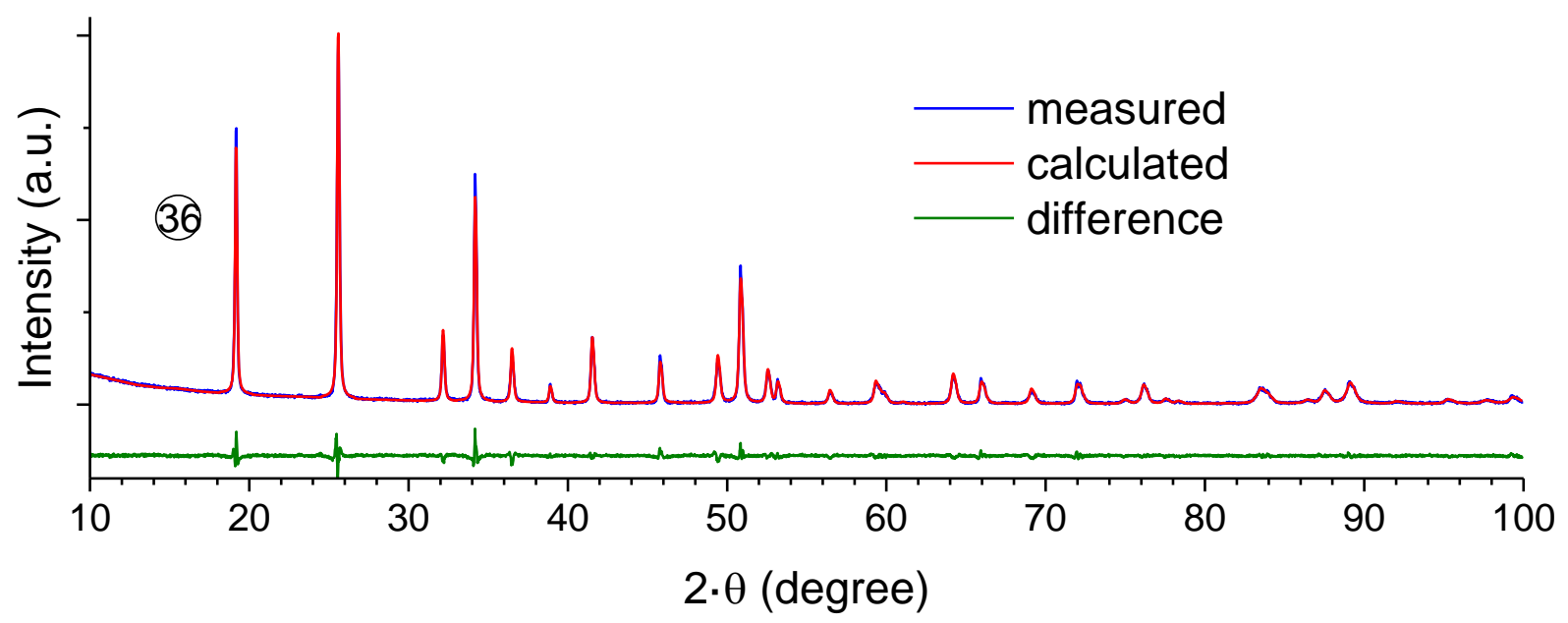

Figure 11. PXRD diagram, calculated and difference profile after Rietveld refinement obtained for $\mathrm{CeSiO}_{4}$ prepared under hydrothermal conditions $\left(\mathrm{T}=150^{\circ} \mathrm{C}, \mathrm{t}=20\right.$ days, Ar-atmosphere), in nitric medium, with $\mathrm{C}_{\mathrm{Ce}(\mathrm{III})} \approx \mathrm{C}_{\mathrm{Si}} \approx 1 \mathrm{~mol} \cdot \mathrm{L}^{-1}$ and $\mathrm{pH}_{\text {initial }}=8.0$ (36).

\section{Characterization of $\mathrm{CeSiO}_{4}$ sample obtained in optimized conditions}

From the multiparametric study developed, the set of optimal conditions to prepare pure $\mathrm{CeSiO}_{4}$ (Figure 11) and optimize its yield of formation, corresponds to high $\mathrm{Ce}(\mathrm{III})$ and silicate concentrations (i.e. $1 \mathrm{~mol} \cdot \mathrm{L}^{-1}$ ) and $\mathrm{pH}$ value adjusted to 8.0 with the help of $\mathrm{NaOH}$. Hydrothermal treatment is performed at $150^{\circ} \mathrm{C}$ for 20 days under inert atmosphere (Ar).

Rietveld refinements performed on the XRD diagrams confirmed that $\mathrm{CeSiO}_{4}$ crystallized in the zircon structure (141/amd space group) with the following unit cell parameters: $a=6.9603(1) \AA, \quad c=6.1946(2) \AA, \quad$ i.e. $\quad V=300.11(2) \AA^{3}$ (Table S3). These values are close to those reported by Skakle et $\quad$ al. $^{30} \quad(a=6.9564(3) \AA \quad$ and $\quad c=6.1953(4) \AA$, i.e. $\mathrm{V}=299.80(3) \AA^{3}$ ).

In such conditions, neither silica nor cerium oxide features were observable from infrared and Raman spectrometric measurement (Figure S4 and Figure S5). Moreover, infrared and Raman spectra confirmed the same features for $\mathrm{CeSiO}_{4}$ than for isostructural zircon-type silicate (Table 2).

The characterization of $\mathrm{CeSiO}_{4}$ by Scanning Electron Microscopy clearly showed the formation of square based bipyramids crystals with less than $1 \mu \mathrm{m}$ in length. This morphology is clearly characteristic of zircon-type actinide silicates (Figure 12). ${ }^{32}$

As suggested by Dickson et al. ${ }^{32}$, heating of $\mathrm{CeSiO}_{4}$ under inert atmosphere (Ar) or in air revealed that the phase was stable up to $1000^{\circ} \mathrm{C}$. The unit-cell parameters obtained after heating at this temperature were found to $a=6.9446(1) \AA, c=6.1975$ $\AA$ and $V=298.89(1) \AA^{3}$ (Figure S7 and Table S3). It showed the decrease of the $a$ unit cell parameters and the increase of the $c$ unit cell parameter, compared to those obtained just after hydrothermal treatment. Such a difference could result from the elimination of hydroxide groups in the structure. ${ }^{38,55}$

Table 2. Assignment of the bands associated to silicate groups observed by Raman and IR spectra for $\mathrm{CeSiO}_{4}$ and comparison with some other zircon-type compounds.

\section{Raman spectroscopy}

\section{Infrared spectroscopy}

$\mathbf{v}_{\mathbf{2}}$

$\begin{array}{cl}\mathrm{ZrSiO}_{4}{ }^{62,63} & 439 \mathrm{~cm}^{-1} \\ \mathrm{HfSiO}_{4}{ }^{64-66} & 448 \mathrm{~cm}^{-1} \\ \mathrm{ThSiO}_{4}{ }^{39} & 438 \mathrm{~cm}^{-1} \\ \text { USiO }_{4}{ }^{39} & 424 \mathrm{~cm}^{-1} \\ \mathrm{CiO}_{\text {(this study) }} & 416 \mathrm{~cm}^{-1}\end{array}$

$\mathrm{CeSiO}_{4}$ (this study) $\mathbf{v}_{4}$

$\begin{array}{lll}608 \mathrm{~cm}^{-1} & 974 \mathrm{~cm}^{-1} & 1008 \mathrm{~cm}^{-1} \\ 620 \mathrm{~cm}^{-1} & 984 \mathrm{~cm}^{-1} & 1018 \mathrm{~cm}^{-1} \\ 592 \mathrm{~cm}^{-1} & 887 \mathrm{~cm}^{-1} & 914 \mathrm{~cm}^{-1} \\ 591 \mathrm{~cm}^{-1} & 906 \mathrm{~cm}^{-1} & 919 \mathrm{~cm}^{-1} \\ 592 \mathrm{~cm}^{-1} & 903 \mathrm{~cm}^{-1} & 919 \mathrm{~cm}^{-1}\end{array}$

$\mathbf{v}_{2}$

$431 \mathrm{~cm}^{-1}$
$430 \mathrm{~cm}^{-1}$
$445 \mathrm{~cm}^{-1}$
$437 \mathrm{~cm}^{-1}$
$431 \mathrm{~cm}^{-1}$

$\mathbf{v}_{4}$

$\begin{array}{lll}620 \mathrm{~cm}^{-1} & 866 \mathrm{~cm}^{-1} & 1049 \mathrm{~cm}^{-1} \\ 610 \mathrm{~cm}^{-1} & 890 \mathrm{~cm}^{-1} & 1020 \mathrm{~cm}^{-1} \\ 584 \mathrm{~cm}^{-1} & 823 \mathrm{~cm}^{-1} & 986 \mathrm{~cm}^{-1} \\ 578 \mathrm{~cm}^{-1} & 850 \mathrm{~cm}^{-1} & 970 \mathrm{~cm}^{-1} \\ 572 \mathrm{~cm}^{-1} & 800 \mathrm{~cm}^{-1} & 984 \mathrm{~cm}^{-1}\end{array}$

is unfavorable to the formation of $\mathrm{CeSiO}_{4}$ (and surely to the existence of this cerium silicate complexes) consequently to the precipitation of $\mathrm{SiO}_{2} \cdot{ }^{14}$ On the contrary, the precipitation of $\mathrm{Ce}(\mathrm{OH})_{3}$ (and its oxidation to form $\mathrm{CeO}_{2}$ ) could limit the availability of cerium for higher $\mathrm{pH}$ values. ${ }^{46}$ The same considerations with $\mathrm{Ce}$ (IV) precursor lead to conclude that the coexistence of free cerium and silicate ions in solution is not possible, which prevents the formation of $\mathrm{CeSiO}_{4}$. Moreover, the direct formation of $\mathrm{CeSiO}_{4}$ from ceria and silica is also during the preparation of $\mathrm{ThSiO}_{4}{ }^{38}$ Working at lower $\mathrm{pH}$ values 


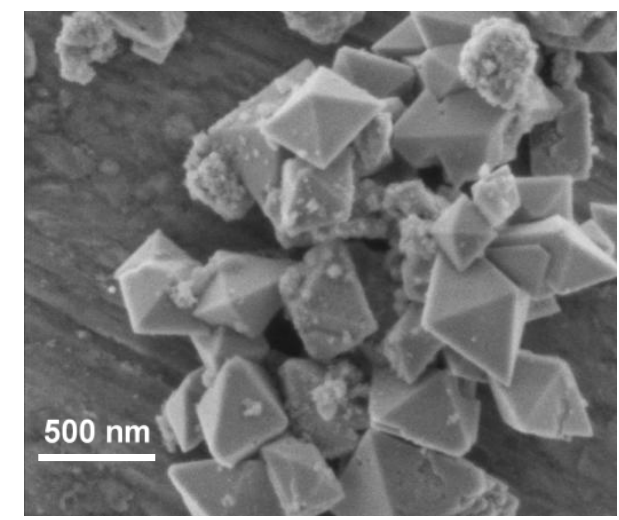

Figure 12. SEM micrograph of $\mathrm{CeSiO}_{4}$ sample prepared under hydrothermal conditions $\left(T=150^{\circ} \mathrm{C}, \mathrm{t}=20\right.$ days, Ar-atmosphere), in nitric medium, with $\mathrm{C}_{\mathrm{Ce}(I I I)} \approx \mathrm{C}_{\mathrm{Si}} \approx 1 \mathrm{~mol} \cdot \mathrm{L}^{-1}$ and $\mathrm{pH}_{\text {initial }}=8.0$ (36)

limited from a thermodynamic point of view, due to its instability compared to the mixture of $\mathrm{CeO}_{2}$ and $\mathrm{SiO}_{2} .{ }^{13}$

The formation of $\mathrm{CeSiO}_{4}$ from $\mathrm{Ce}(\mathrm{III})$ and silicate ions in solution may result from the very slow in-situ oxidation of the suspected Ce(III)-silicate complex. Increasing temperature (i.e. increasing oxidation rate) induce the formation of $\mathrm{SiO}_{2}$ and $\mathrm{CeO}_{2}$ (obtained by precipitation than ageing of $\mathrm{Ce}(\mathrm{OH})_{4}$ ). Thus, it seems crucial to maintain $\mathrm{Ce}$ (IV) at a low concentration in solution in order to avoid the rapid establishment of oversaturation conditions regarding to $\mathrm{Ce}(\mathrm{OH})_{4}$. It is also the reason why $\mathrm{CeSiO}_{4}$ was never prepared from $\mathrm{Ce}(\mathrm{IV})$, due to its very strong tendency to hydrolysis. This also suggests that $\mathrm{CeSiO}_{4}$ could not be prepared as soon as $\mathrm{CeO}_{2}$ was formed. The absence of evolution of PXRD diagrams when performing hydrothermal treatment of $\mathrm{CeO}_{2}+\mathrm{CeSiO}_{4}$ mixtures at $250^{\circ} \mathrm{C}$ and for large $\mathrm{pH}$ range support the fact that the conversion of $\mathrm{CeO}_{2}$ to $\mathrm{CeSiO}_{4}$ is unfavorable.

In order to support these observations, speciation simulations were performed using PHREEQC 2 software aiming at determining the conditions which may favor the formation of silicate-based precursor in the starting solution. Since no complexation constant was available for both $\mathrm{Ce}$ (III)- and $\mathrm{Ce}(\mathrm{IV})$-silicate species, the respective constants have been extrapolated. These results were based on the apparent linear relationship reported by Thakur et al. ${ }^{67}$ between the first hydrolysis constant of a metal ion and its complexation by $\mathrm{H}_{3} \mathrm{SiO}_{4}{ }_{4}$. In order to be more representative, the constants were calculated considering only elements showing the same oxidation state than cerium (Table S4 and Figure S8). Based on these hypotheses, the complexation constants were evaluated to $\log \beta^{\circ}\left(\mathrm{Ce}{ }^{\text {III }}\left(\mathrm{OSi}(\mathrm{OH})_{3}\right)^{2+}\right)=7.8$ and $\log \beta^{\circ}\left(\mathrm{Ce}^{\mathrm{IV}}\left(\mathrm{OSi}(\mathrm{OH})_{3}\right)^{3+}\right)=$ 11.7.

PHREEQC 2 calculations were performed at $\mathrm{C}_{\mathrm{Si}} \approx \mathrm{C}_{\mathrm{Ce}}=$ $0.21 \mathrm{~mol} \cdot \mathrm{L}^{-1}$ at room temperature considering the data reported in Table S2 and extrapolated for Ce(III)- and Ce(IV)silicate species. Due to some lacks in the thermodynamic data associated to the temperatures considered for the hydrothermal treatment, simulation for higher temperatures was not possible.
The results of these simulations showed that the formation of the $\mathrm{Ce}^{\mathrm{IV}}\left(\mathrm{OSi}(\mathrm{OH})_{3}\right)^{3+}$ complex in the reactive media is strongly limited for $\mathrm{Ce}(\mathrm{IV})$ due to its significant hydrolysis (Figure 13). Therefore, in these conditions, the formation of Ce-silicate species appears to be strongly limited because of the formation of $\mathrm{Ce}(\mathrm{IV})$ hydroxide species and their rapid evolution to $\mathrm{CeO}_{2}$.

Due to its lower tendency to hydrolyze, Ce(III)-based system does not follow the same behavior than Ce(IV). Consequently, $\mathrm{Ce}^{\text {III }}\left(\mathrm{OSi}(\mathrm{OH})_{3}\right)^{2+}$ complex appears as a predominant specie on a wide $\mathrm{pH}$ range in reductive conditions (Figure 13). It could then be inferred that this silicate specie evolved by in situ oxidation leading to the formation of $\mathrm{CeSiO}_{4}$ while the formation of cerium oxide is disadvantaged.

Same simulations performed in the presence of carbonate ions confirmed that the formation of $\mathrm{Ce}^{\mathrm{III}}\left(\mathrm{OSi}(\mathrm{OH})_{3}\right)^{2+}$ is strongly limited by the existence of $\mathrm{Ce}(\mathrm{III})$-carbonate complexes (Figure S9). This can explain why $\mathrm{CeSiO}_{4}$ is not formed in such experimental conditions.

Therefore, all the speciation calculations support the key role played by $\mathrm{Ce}$ (III)-silicate complex during the formation of $\mathrm{CeSiO}_{4}$. However, the results have to be considered with caution because of the poor knowledge of experimental data associated to cerium silicate complexes. This highlights the necessity of studying the aqueous chemistry of cerium in order

(a)

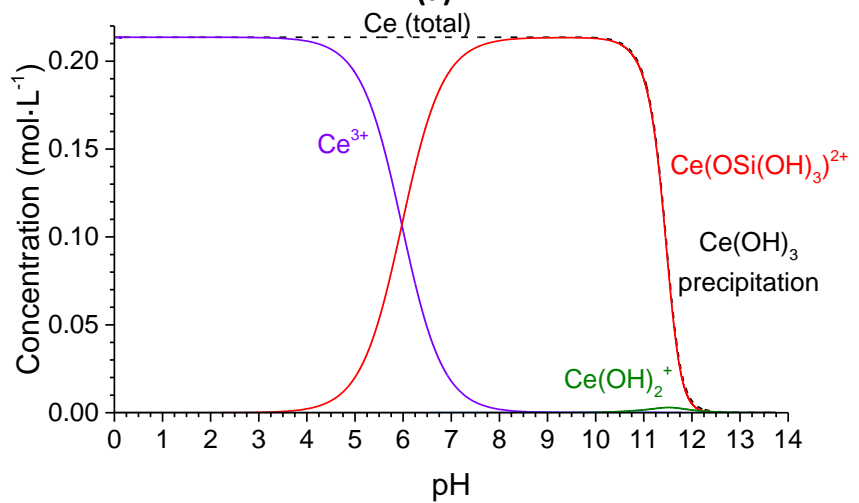

(b)

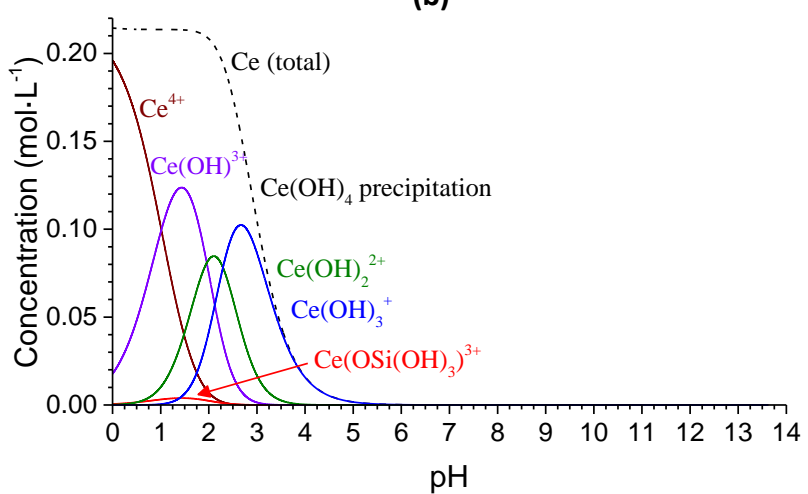

Figure 13. Speciation diagrams of $\mathrm{Ce}$ (III) (a) and $\mathrm{Ce}(\mathrm{IV})$ (b) determined by PhreeqC calculations at room temperature with $\mathrm{C}_{\mathrm{Si} \text { total }} \approx \mathrm{C}_{\text {Ce total }}=0.21 \mathrm{~mol} \cdot \mathrm{L}^{-1}$ Thermodynamics data considered for these calculations are gathered in Table S3. 
to thoroughly understand the mechanism of $\mathrm{CeSiO}_{4}$ formation.

\section{Conclusions}

The formation of $\mathrm{CeSiO}_{4}$ was successfully achieved from cerium(III) precursor under inert atmosphere. The yield of $\mathrm{CeSiO}_{4}$ synthesis was found to be strongly dependent on the concentration of the reactants and of the $\mathrm{pH}$ of the reactive media. The formation of $\mathrm{CeSiO}_{4}$ may also require the formation of cerium-silicate complexes in solution. Also, temperature plays an important role in the preparation of $\mathrm{CeSiO}_{4}$, which is formed between $40^{\circ} \mathrm{C}$ and $150^{\circ} \mathrm{C}$. The oxidation state of cerium has a huge impact, supported by kinetic and thermodynamic considerations. Indeed, $\mathrm{Ce}$ (IV) concentration has to be maintained to low level in order to avoid the formation of $\mathrm{Ce}(\mathrm{OH})_{4}$ thus of $\mathrm{CeO}_{2}$ by ageing.

Furthermore, these observations shed new light on the reactivity of cerium(III) in the presence of silicate species in solution. With this aim, the identification of potential cerium(III) silicate species in solution, the determination of associated complexation constants and their role in the $\mathrm{CeSiO}_{4}$ synthesis, constitute key issues. Since silicate ions are abundant in environmental conditions representative of underground repository (either in granite and clay environments), such information are important to consider in order to better understand the potential reactivity of actinide in silicate rich environments, especially for plutonium.

\section{Supporting information}

Table S1 reporting the synthesis parameters for all the $\mathrm{CeSiO}_{4}$ hydrothermal syntheses presented here. Table S2 gathering the thermodynamic constants used for PHREEQC simulation. ${ }^{35}$, 54, 68 Table $\mathbf{S 3}$ gathering the unit-cell parameters of $\mathrm{CeSiO}_{4}$ obtained for hydrothermally synthesized samples and after $1000^{\circ} \mathrm{C}$ heat treatment. Table S4 gathering the $M(I I I)$ and $\mathrm{M}(\mathrm{IV})$ complexation constants with hydroxide and o-silicate used to determine $\log \beta\left(\mathrm{Ce}\left(\mathrm{OSi}(\mathrm{OH})_{3}\right)^{2+}\right)$ and $\log \beta\left(\mathrm{Ce}\left(\mathrm{OSi}(\mathrm{OH})_{3}\right)^{3+}\right){ }^{15,35,53,54,67,69-72}$

Figure S1 representing the infrared spectra obtained for samples prepared under hydrothermal conditions with starting silicate and cerium(IV) at different $\mathrm{pH}$. Figure S2 representing the infrared spectra obtained for $\mathrm{CeSiO}_{4}$ samples synthesized under hydrothermal conditions at different $\mathrm{pH}$. Figure $\mathbf{S 3}$ representing the infrared spectra obtained for $\mathrm{CeSiO}_{4}$ samples synthesized under hydrothermal conditions at various temperature. Figure $\mathbf{S 4}$ representing the infrared spectrum of $\mathrm{CeSiO}_{4}$ pure sample synthesized in optimized conditions. Figure $\mathbf{S 5}$ representing the Raman spectrum of $\mathrm{CeSiO}_{4}$ pure sample synthesized in optimized conditions. Figure S6 representing the Rietveld refinement of $\mathrm{CeSiO}_{4}$ sample synthesized in hydrochloric acid media. Figure $\mathbf{S 7}$ representing the Rietveld refinement of PXRD diagram obtained after heating $\mathrm{CeSiO}_{4}$ sample above $1000^{\circ} \mathrm{C}$. Figure $\mathbf{S 8}$ representing the linear relationship between $\log \beta\left(\mathrm{M}\left(\mathrm{OSi}(\mathrm{OH})_{3}\right)\right)$ and $\log \beta(\mathrm{M}(\mathrm{OH}))$ according to the data gathered in Table S4.
Figure $\mathbf{5 9}$ representing $\mathrm{Ce}$ (III) speciation diagram in carbonate ions rich reactive media.

\section{Conflicts of interest}

There are no conflicts to declare.

\section{Acknowledgements}

The authors would like to thank R. Podor, J. Lautru and V. Trillaud (from ICSM) for supporting SEM experiments.

\section{Notes and references}

1. J. Felsche, Die Naturwissenschaften, 1969, 56, 325-326.

2. A. C. Tas and M. Akinc, Powder diffraction, 1992, 7, 219-222.

3. H. A. M. van Hal and H. T. Hintzen, Journal of Alloys and Compounds, 1992, 179, 77-85.

4. A. C. Tas and M. Akinc, Journal of the American Ceramic Society, 1994, 77, 2968-2970.

5. A. C. Tas and M. Akinc, Journal of the American Ceramic Society, 1994, 77, 2953-2960.

6. M. Ghannadi Marageh, S. Waqif Husain, A. R. Khanchi and S. J. Ahmady, Applied Radiation and Isotopes, 1996, 47, 501505.

7. L. Kępiński, D. Hreniak and W. Stręk, Journal of Alloys and Compounds, 2002, 341, 203-207.

8. L. Kępiński, M. Wołcyrz and M. Marchewka, Journal of Solid State Chemistry, 2002, 168, 110-118.

9. S. Zec and S. Boskovic, Journal of Materials Science, 2004, 39, 5283-5286.

10. S. Zec, S. Bošković, Ž. Bogdanov and N. Popović, Materials Chemistry and Physics, 2006, 95, 150-153.

11. S. Zec, S. Bošković, M. Hrovat and M. Kosec, Journal of the European Ceramic Society, 2007, 27, 523-526.

12. C. Lopez, Ph.D. Thesis. Université de Paris XI, 2002.

13. E. D. A. Ferriss, R. C. Ewing and U. Becker, American Mineralogist, 2010, 95, 229-241.

14. R. K. Iler, The chemistry of silica: solubility, polymerization, colloid and surface properties, and biochemistry, John Wiley \& Sons: Hoboken, NJ, 1979.

15. V. Neck and J. I. Kim, Radiochimica Acta, 2001, 89, 1-16.

16. C. Frondel, Geological Survey Bulletin, 1958, 1064

17. L. R. Stieff, T. W. Stern and A. M. Sherwood, Science, 1955, 121, 608-609.

18. C. Frondel and R. L. Collette, The American Mineralogist, 1957, 42, 759-765.

19. H. R. Hoekstra and L. H. Fuchs, Science, 1956, 123, 105.

20. J. Janeczek and R. C. Ewing, Materials Research Society, Symposium Proceedings, 1992, 257, 497-504.

21. C. Hennig, S. Weiss, D. Banerjee, E. Brendler, V. Honkimäki, G. Cuello, A. Ikeda-Ohno, A. C. Scheinost and H. Zänker, Geochimica et Cosmochimica Acta, 2013, 103, 197-212.

22. I. Dreissig, S. Weiss, C. Hennig, G. Bernhard and H. Zänker, Geochimica et Cosmochimica Acta, 2011, 75, 352-367. 
23. R. Husar, S. Weiss, C. Hennig, R. Hübner, A. Ikeda-ohno and H. Zänker, Environmental Science \& Technology, 2015, 49, 665-671.

24. H. Zänker and C. Hennig, Journal of Contaminant Hydrology, 2014, 157, 87-105.

25. H. Zänker, S. Weiss, C. Hennig, V. Brendler and A. IkedaOhno, Chemistry Open, 2016, 5, 174-182.

26. A. B. Kersting, D. W. Efurd, D. L. Finnegan, D. J. Rokop, D. K. Smith and J. L. Thompson, Nature, 1999, 397, 56-59.

27. C. Keller, Nukleonik, 1963, 5, 41-48.

28. R. J. Finch and J. M. Hanchar, Reviews in Mineralogy and Geochemistry, 2003, 53, 1-25.

29. J. A. Speer, Reviews in Mineralogy and Geochemistry, 1980, 5, 113-135.

30. J. M. S. Skakle, C. L. Dickson and F. P. Glasser, Powder diffraction, 2000, 15, 234-238.

31. J. Schlüter, T. Malcherek and T. A. Husdal, Neues Jahrbuch für Mineralogie - Abhandlungen, 2009, 186, 195-200.

32. C. L. Dickson and F. P. Glasser, Cement and Concrete Research, 2000, 30, 1619-1623.

33. C. Frontera and J. Rodriguez-Carvajal, Physica B: Condensed Matter, 2003, 335, 219-222.

34. D. L. Parkhurst and C. A. J. Appelo, U.S. Department of Interior; U.S. Geological Survey, 1999, Water-Resources Investigations Report 99-4259.

35. E. Giffaut, M. Grivé, P. Blanc, P. Vieillard, E. Colàs, H. Gailhanou, S. Gaboreau, N. Marty, B. Madé and L. Duro, Applied Geochemistry, 2014 49, 225-236.

36. A. Mesbah, S. Szenknect, N. Clavier, J. Lozano-Rodriguez, C. Poinssot, C. Den Auwer, R. C. Ewing and N. Dacheux, Inorganic Chemistry, 2015, 54, 6687-6696.

37. P. Estevenon, E. Welcomme, S. Szenknect, A. Mesbah, P. Moisy, C. Poinssot and N. Dacheux, Inorganic Chemistry, 2018, 57, 12398-12408.

38. P. Estevenon, E. Welcomme, S. Szenknect, A. Mesbah, P. Moisy, C. Poinssot and N. Dacheux, Inorganic Chemistry, 2018, 57, 9393-9402.

39. N. Clavier, S. Szenknect, D. T. Costin, A. Mesbah, C. Poinssot and N. Dacheux, Spectrochimica Acta Part A: Molecular and Biomolecular Spectroscopy 118, 2014, 118, 302-307.

40. N. Clavier, S. Szenknect, D. T. Costin, A. Mesbah, J. Ravaux, C. Poinssot and N. Dacheux, Journal of Nuclear Materials, 2013, 441, 73-83.

41. D. T. Costin, Ph.D. Thesis. Université de Montpellier 2, 2012.

42. D. T. Costin, A. Mesbah, N. Clavier, N. Dacheux, C. Poinssot, S. Szenknect and J. Ravaux, Inorganic Chemistry, 2011, 50, 11117-11126.

43. D. T. Costin, A. Mesbah, N. Clavier, S. Szenknect, N. Dacheux, C. Poinssot, J. Ravaux and H. P. Brau, Progress in Nuclear Energy, 2012, 57, 155-160.

44. S. Szenknect, D. T. Costin, N. Clavier, A. Mesbah, C. Poinssot, P. Vitorge and N. Dacheux, Inorganic Chemistry, 2013, 52, 6957-6968.

45. C. Artini, M. Pani, M. M. Carnasciali, M. T. Buscaglia, J. R. Plaisier and G. A. Costa, Inorganic Chemistry, 2015, 15, 41264137.
46. B. Bouchaud, J. Balmain, G. Bonnet and F. Pedraza, Journal of Rare Earths, 2012, 30, 559-562.

47. D. Rai, M. Yui, D. A. Moore, G. J. Lumetta, K. M. Rosso, Y. Xia, A. R. Felmy and F. N. Skomurski, Journal of Solution Chemistry, 2008, 37, 1725-1746.

48. T. S. Neill, K. Morris, C. I. Pearce, N. K. Sherriff, M. G. Burke, P. A. Chater, A. Janssen, L. S. Natrajan and S. Shaw, Environmental Science \& Technology, 2018, 52, 9118-9127.

49. S. Szenknect, A. Mesbah, T. Cordara, N. Clavier, H. P. Brau, X. Le Goff, C. Poinssot, R. C. Ewing and N. Dacheux, Geochimica et Cosmochimica Acta, 2016, 181, 36-53.

50. C. Riglet-Martial, P. Vitorge and V. Calmon, Radiochimica Acta, 1998, 82, 69-76.

51. P. Vitorge, H. Capdevila and L. Delmau, L'Aquila (Italia), 1995.

52. M. H. Rand, J. Fuger, I. Grenthe, V. Neck and D. Rai, Chemical thermodynamics of thorium, Issy-les-Moulineaux, France, 2009.

53. R. Guillaumont, T. Fanghänel, V. Neck, J. Fuger, D. A. Palmer, I. Grenthe and M. H. Rand, Update on the chemical thermodynamics of uranium, neptunium, plutonium, americium and technetium, Elsevier, Issy-les-Moulineaux, France, 2003.

54. S. A. Hayes, P. Yu, T. J. O'Keefe, M. J. O'Keefe and J. O. Stoffer, Journal of The Electrochemical Society, 2006, 149, C623-C630.

55. C. Frondel, United State Departement of the Interior Geological Survey, 1953, Trace Elements Investigation Report 327.

56. T. N. Tarkhova, N. N. Mironov and I. A. Grishin, Journal of Structural Chemistry, 1970, 11, 515-516.

57. P. V. Klevtsov, V. M. Bembel' and Z. A. Grankina, Journal of Structural Chemistry, 1969, 10, 543-547.

58. R. A. Zehnder, D. L. Clark, B. L. Scott, R. J. Donohoe, P. D. Palmer, W. H. Runde and D. E. Hobart, Inorganic Chemistry, 2010, 49, 4781-4790.

59. Z. Guo, F. Du, G. Li and Z. Cui, Inorganic Chemistry, 2006, 45, 4167-4169.

60. Y. V. Belovitskaya, I. V. Pekov and Y. K. Kabalov, Crystallography Reports, 2000, 45, 26-29.

61. J. Bentzen, P. Husum and O. Soerensen, High Tech Ceramics. Proceedings, 1987, 38, 385-398.

62. P. Dawson, M. M. Hargreave and G. R. Wilkinson, Journal of Physics C: Solid State Physics, 1971, 4, 240-256.

63. R. W. G. Syme, D. J. Lockwood and H. J. Kerr, Journal of Physics C: Solid State Physics, 1977, 10, 1335-1348.

64. P. W. O. Hoskin and K. A. Rodgers, European Journal of Solid State and Inorganic Chemistry, 1996, 33, 1111-1121.

65. J. H. Nicola and H. N. Rutt, Journal of Physics C: Solid State Physics, 1974, 7, 1381-1386.

66. R. Caruba, A. Baumer and G. Turco, Geochimica et Cosmochimica Acta, 1975, 39, 11-26.

67. P. Thakur, D. K. Singh and G. R. Choppin, Inorganica Chimica Acta, 2007, 360, 3705-3711.

68. D. Ferri, I. Grenthe, S. Hietanen and F. Salvatore, Acta Chemica Scandinavica, 1983, A37, 359-365.

69. K. Spahiu and J. Bruno, SKB, 1995, SKB Technical Report 9535. 
70. M. P. Jensen, Ph.D. Thesis. Florida State University, 1994.

71. R. A. Porter and W. J. J. Weber, Journal of Inorganic and Nuclear Chemistry, 1971, 33, 2443-2449.

72. A. B. Yusov, A. M. Fedosseev and C. H. Delegard, Radiochimica Acta, 2004, 92, 869-881. 